\title{
Pengaruh Personal Selling terhadap Minat Beli Produk PRUlink Generasi Baru Nasabah Prudential Life Assurance Indonesia
}

\author{
Nico Aprianto, Diah Ayu Candraningrum \\ Nico.915160010@stu.untar.ac.id,diahc@fikom.untar.ac.id
}

Fakultas Ilmu Komunikasi Universitas Tarumanagara

\begin{abstract}
This study aims to examine how strong the influence of Personal Selling on Interest in Purchasing New Generation PRUlink products for Prudential Life Assurance Indonesia customers. The data of this study were obtained from the results of questionnaires of 153 Prudential Life Assurance Indonesia customers regarding interest in purchasing New Generation PRUlink products. In this study the research method used is quantitative which aims to test the instrument using the validity, reliability and normality test. The results of data processing using SPSS states that the variable Personal selling $(X)$ influences significantly to the variable purchase interest $(Y)$. Correlation coefficient test results explained there will be a strong relationship between Personal selling $(X)$ to the variable buying interest $(Y)$. Meanwhile, the dimensions that support the effectiveness of personal selling include ability approaching, presentation, handling objection, and closing. The ability to start communication, presenting products, being able to answer prospective customer questions, and close communication well, be an attraction for prospective customers to be the customer.
\end{abstract}

Keywords : personal selling, prudential life assurance, purchase intention

\begin{abstract}
Abstrak
Penelitian ini bertujuan untuk meneliti seberapa kuat pengaruh Personal Selling terhadap Minat Beli produk PRUlink Generasi Baru nasabah Prudential Life Assurance Indonesia. Data penelitian diperoleh melalui penyebaran kuesioner terhadap 153 nasabah Prudential Life Assurance Indonesia mengenai minat beli produk PRUlink Generasi Baru. Penelitian ini merupakan penelitian kuantitatif menggunakan metode survei. Pengujian instrumen berupa uji Validitas, Reliabilitas dan Normalitas. Pengolahan data menggunakan Statistical Package for Social Sciences (SPSS) dan memperoleh hasil bahwa variabel Personal selling (X) berpengaruh secara signifikan terhadap variabel Minat beli (Y). Hasil uji koefisien korelasi menjelaskan akan adanya hubungan yang kuat antara Personal selling (X) terhadap variabel Minat beli (Y). Adapun, dimensi yang mendukung efektivitas personal selling meliputi kemampuan pendekatan, presentasi, mengatasi keberatan, dan penutupan. Kemampuan dalam membuka komunikasi, mempresentasikan produk, mampu menjawab pertanyaan calon nasabah, dan menutup komunikasi dengan baik, sehingga mampu menarik calon nasabah membeli produk asuransi.
\end{abstract}

Kata Kunci : minat beli, personal selling, prudential life assurance

\section{Pendahuluan}

Indonesia tercatat memiliki jumlah penduduk sebesar 271,107,331 jiwa dan di dunia menduduki negara yang memiliki penduduk terbanyak dengan peringkat keempat (Worldometers, 2019). Jumlah tersebut menjadi gambaran banyaknya kebutuhan yang harus dipenuhi. Maslow (Iskandar, 2016) menjelaskan bahwa 
perbedaan individu menunjukkan perbedaan kebutuhan yang dapat dirangkum menjadi lima tahapan. Tahap pertama, kebutuhan fisiologis sebagai kebutuhan yang paling mendasar, seperti makanan, minuman, dan sex. Tahap kedua yaitu kebutuhan rasa aman, seperti keamanan secara fisik, stabilitas, dependensi (kebergantungan), dan perlindungan. Tahap ketiga yaitu kebutuhan cinta dan kepemilikan, seperti berteman, memiliki pasangan, atau menjadi bagian di dalam suatu komunitas. Tahap keempat, kebutuhan untuk dihargai. Tahap kelima, kebutuhan aktualisasi diri. Pemenuhan kebutuhan tersebut berlangsung secara bertahap.

Kebutuhan fisiologis bersifat primer dan berlangsung setiap hari. Menariknya, kerap kali individu yang telah tercukupi sandang, pangan, dan papannya masih memiliki kekhawatiran terhadap adanya ancaman atau perubahan fluktuatif yang mendadak. Kebutuhan terhadap rasa aman merefleksikan keinginan untuk mengamankan imbalan, adanya penjaminan hari esok, kekhawatiran terhadap adanya penyakit kritis yang mendadak, atau kondisi tidak produktif ketika pensiun. Menanggapi pentingnya pemenuhan tahap kedua, maka tidak sedikit masyarakat yang menginvestasikan imbalan kerjanya di dalam perusahaan asuransi (Feist, Feist \& Roberts, 2013).

Majalah Investor mencatat bahwa sebanyak 21 perusahaan asuransi nasional meraih predikat 'Asuransi Terbaik 2018' PT. Prudential Life Assurance meraih posisi terbaik pada kelompok asuransi jiwa papan atas, dengan asset di atas Rp 25 triliun, disusul oleh PT Asuransi Jiwasraya (Persero), dan PT AIA Financial (Rachim, 2018). Saat ini, Prudential Indonesia memiliki lebih dari 250.000 tenaga pemasar yang tersebar di Indonesia. Sepanjang 2018 total aset Prudential Indonesia mencapai Rp 78,9 Triliun dan juga perusahaan berhasil mencetak pendapatan premi sebesar Rp 25,4 Triliun tertinggi di industri asuransi jiwa. Prudential Indonesia tetap mempertahankan eksistensi serta meningkatkan inovasinya seperti diluncurkan tahun 2018 Produk PRUlink Generasi Baru (Sulaiman, 2019).

PRUlink Generasi Baru merupakan inovasi yang ditawarkan oleh Prudential Life Assurance yaitu perlindungan jiwa sekaligus alokasi investasi positif sejak nasabah pertama kali membayar premi. Produk baru ini turut diperlengkapi dengan adanya PRUbooster investasi dan PRUbooster proteksi (Prudential, 2018). Sendra (2004) dalam Fatimah (2018) menjelaskan bahwa seorang agen merupakan ujung tombak perusahaan asuransi jiwa. Hal ini turut dilatarbelakangi dengan adanya penelitian yang dilakukan oleh penelitian Muchina dan Okello (2016) bahwa personal selling telah mempengaruhi brand performance perusahaan sepatu ritel di distrik pusat bisnis di Nairobi. Nama baik perusahaan dan seberapa besar kemungkinan calon nasabah setuju menggunakan jasa asuransi jiwa terutama asuransi Prudential Life Assurance tergantung dari cara para agen mengkomunikasikan produk yang ingin ditawarkan. Salah satu bagian dari integrated marketing communication yang dipakai oleh agen untuk mengedukasi, sosialisasi serta menawarkan produknya adalah personal selling. Teknik personal selling merupakan cara penting yang dapat dilakukan untuk mempersuasif calon nasabah, walaupun terdapat media lain yang turut mempromosikan produk, hal ini sesuai dengan hasil penelitian mengenai kontrubsi dari personal selling dalam kegiatan pemasaran khususnya dikondisikan saat ini (Kusniadji, 2017).

Dengan adanya teknik personal selling penulis berharap bisa meneliti seberapa kuat Personal Selling dapat berpengaruh terhadap minat beli Produk "PRUlink Generasi Baru" nasabah Prudential Life Assurance Indonesia. 
Nico Aprianto, Diah Ayu Candraningrum: Pengaruh Personal Selling terhadap Minat Beli Produk PRUlink Generasi Baru Nasabah Prudential Life Assurance Indonesia

Kotler dan Armstrong (2012) mendefisikan pemasaran sebagai proses sosial dan manajerial, yang di dalamnya terdapat interaksi individu dan kelompok dalam menciptakan, menawarkan, dan mempertukarkan produk yang bernilai serta dibutuhkan dengan pihak lain. Adapun, Kotler dan Keller (2009) menjelaskan bahwa komunikasi pemasaran didefinisikan sebagai sarana bagi perusahaan untuk memberikan informasi, membujuk, dan mengingatkan konsumen baik secara langsung maupun tidak mengenai produk yang dijual.

Sarastuti (2017) mengemukakan bahwa guna meningkatkan penjualan bisnis, maka dibutuhkan strategi komunikasi pemasaran, antara lain, iklan (advertisement), promosi penjualan (sales promotion), penjualan personal (personal selling), pemasaran langsung (direct marketing), dan hubungan masyarakat (public relation). Diantara kelima strategi komunikasi pemasaran, peneliti tertarik untuk meneliti mengenai strategi personal selling.

Kotler \& Armstrong (2014) mengemukakan bahwa personal selling terdiri dari interaksi antara penjual dengan calon pelanggan atau pelanggan dalam membuat penjualan dan mempertahankan hubungan. Definisi serupa dinyatakan oleh Nickels dalam Priansa (2017) bahwa personal selling merupakan interaksi antar individu, saling bertatap muka yang ditujukan untuk menciptakan, memperbaiki, menguasai, atau mempertahankan hubungan pertukaran yang saling menguntungkan dengan pihak lain. Adapun, Tjiptono (2008) dalam Priansa (2017) menyatakan bahwa personal selling merupakan komunikasi langsung antara penjual dan calon konsumen dalam memperkenalkan suatu produk kepada calon konsumen dan membentuk pemahaman mengenai produk sehingga tertarik untuk membeli. Ketiga definisi menegaskan hal yang sama yakni, pemasaran produk dilakukan secara langsung (tatap muka).

Kotler \& Armstrong (2016) mengemukakan bahwa proses personal selling terdiri dari beberapa langkah yang harus dikuasai, yaitu sebagai berikut; (1) Memilih dan menilai prospek (prospecting) sehingga dapat mengidentifikasi dan mengkualifikasikan pelanggan yang potensial. (2) Prapendekatan (preapproach) tahap dimana tenaga penjual mempelajari tentang pelanggan yang prospektif. Elemen perencanaan prapendekatan meliputi obyek penjualan, profil konsumen, dan manfaat bagi konsumen (Machfoedz, 2010); (3) Pendekatan (approach) merupakan tahap untuk membangun atmosfir yang menyenangkan sehingga komunikasi dapat terjalin nyaman dan memunculkan kepercayaan; (4) Presentasi dan demonstrasi (presentation \& demonstration), yakni penjual menjelaskan mengenai produk, manfaatnya, serta efektifitas produk dalam memenuhi kebutuhan nasabah; (5) Mengatasi keberatan (handling objections) yakni tenaga penjual harus mampu berargumentasi dengan secara sopan sehingga mampu mempersuasif calon pembeli; (6) Penutupan (closing), tahap penjualan dimana tenaga penjual meminta calon pembeli untuk membeli; (7) Tindak lanjut (follow up) tindak lanjut kepada pelanggan untuk memastikan kepuasan pelanggan sehingga berpotensi untuk mengulangi bisnis.

Kotler (2005) dalam Siregar (2017) menjelaskan bahwa personal selling memiliki empat kelebihan. Pertama, salesman dapat mencari dan memilih calon pembeli yang potensial sehingga memungkinkan terjadinya penjualan lebih besar. Kedua, salesman dapat memperagakan secara langsung tata cara penggunaan produk, serta menonjolkan kelebihan produk terkait. Ketiga, keterampilan berbicara dapat digunakan oleh salesman untuk mempersuasif calon pembeli. Keempat, salesman dapat secara teratur menanyakan ketersediaan produk di tangan pembeli sehingga penjualan perusahaan dapat terus meningkat. Senada dengan paparan Kotler, 
Tjiptono (2005) dalam Ferdinand (2016) menyatakan bahwa kelebihan dari personal selling adalah komunikasi dengan pelanggan berjalan dinamis sehingga hambatanhambatan yang ada dapat diselesaikan dengan cepat.

Di samping adanya kelebihan terdapat tiga kekurangan dari personal selling, yang dikemukan Siregar (2017). Pertama, biaya operasional, seperti biaya kendaraan mengunjungi konsumen atau menggunakan jasa sales promotion girl (SPG) cukup tinggi. Kedua, tidak semua salesman memiliki kemampuan yang memadai terkait produk dan kebutuhan konsumen. Ketiga, keterbatasan waktu pelatihan sehingga pengerjaan tugas tidak berjalan maksimal. Menurut Engel, minat beli merupakan dorongan dalam diri seseorang untuk menaruh perhatian tanpa paksaan pada suatu produk dan berujung pada pembelian (Ningrum, 2016). Hal senada turut dikemukakan oleh Assael (2002) dalam Diyah (2019) bahwa minat beli adalah kecenderungan konsumen dalam membeli merek yang di ukur dari minat konsumen.

Kotler (2008) dalam Riyanti (2015) menjelaskan empat tahapan produsen dalam menentukan minat beli; (1) Attention, sebagai tahap awal dalam menilai suatu produk atau jasa, termasuk mempelajari produk untuk mendapat informasi; (2) Interest, sebagai tahap calon pelanggan mulai tertarik untuk membeli produk atau jasa yang ditawarkan; (3) Desire, pada tahap ini, calon pelanggan mulai memikirkan dan berdiskusi mengenai produk atau jasa, dan muncul minat yang cukup kuat untuk membeli; (4) Action, pada tahap ini, calon pelanggan telah memiliki keyakinan untuk membeli atau menggunakan produk atau jasa yang ditawarkan.

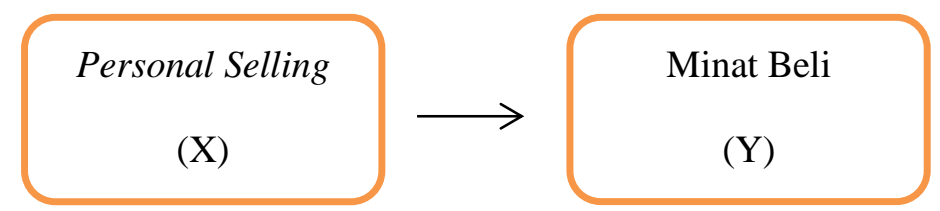

Hipotesis: personal selling mempunyai pengaruh terhadap minat beli produk Prulink Generasi Baru nasabah Prudential Life Assurance.

\section{Metode Penelitian}

Penelitian ini merupakan penelitian kuantitatif. Dalam penelitian ini, penulis menggunakan metode survei. Kriyantono (2009) mengemukakan bahwa metode survei merupakan metode yang menggunakan kuesioner sebagai bentuk pengumpulan data. Tujuannya adalah untuk memperoleh informasi dari responden yang mampu merepresentasikan populasi. Penelitian ini ditujukan kepada nasabah Prudential yang sudah memiliki produk PRUlink Generasi Baru di Indonesia, untuk mengetahui hasil yang diperoleh dari variabel berupa minat beli produk PRUlink Generasi Baru. Pada metode penelitian ini kuesioner atau google form yang di sebarkan secara langsung maupun melalui media online berupa 153 orang responden. Pengolahan data dilakukan dengan memanfaatkan Statistical Package for Social Sciences (SPSS) versi 15.

\section{Hasil Temuan dan Diskusi}

Responden yang dilibatkan dalam penelitian berjumlah 153 orang. Dari hasil pengumpulan data dari 153 orang tersebut dapat diketahui data demografi yaitu, usia responden dan jenis kelamin responden. Semua responden yang berkontribusi merupakan pengguna produk PRUlink Generasi Baru dari sejak tahun 2018 dan telah 
Nico Aprianto, Diah Ayu Candraningrum: Pengaruh Personal Selling terhadap Minat Beli Produk PRUlink Generasi Baru Nasabah Prudential Life Assurance Indonesia

berusia lebih dari 21 tahun. Responden yang berjenis kelamin perempuan adalah 52.3\% dan laki-laki sebesar $47.7 \%$ Berdasarkan hasil data mengenai usia, diketahui bahwa sebanyak 45 responden $(29.4 \%)$ 41-50 tahun, 38 responden $(24,8 \%)$ berusia 21-30 tahun, 37 responden ( $24,2 \%$ ) berusia lebih dari 50 tahun, dan 33 responden $(21,6 \%)$ berusia $31-40$ tahun.

Pengukuran pada populasi memerlukan alat ukur yang valid. Hal ini dikarenakan validitas mengacu pada seberapa jauh suatu ukuran empiris cukup menggambarkan arti sesungguhnya dari konsep yang sedang di teliti (Morissan, 2012). Oleh sebab itu, kevalidan dalam suatu alat ukur berbanding searah dengan maknanya, semakin tinggi validitasnya maka semakin valid alatnya. Nisfiannoor (2013) menjelaskan bahwa pernyataan butir dapat dikatakan valid apabila nilai pada corrected item - total correlation lebih besar dari 0.2. Berdasarkan hasil uji validitas terhadap variabel Personal Selling (X) dan Minat Beli (Y), diperoleh hasil bahwa butir variabel Personal Selling (X) memiliki nilai corrected item - total correlation berkisar 0.4 hingga 0.7. Adapaun, variabel Minat Beli (Y) memiliki nilai corrected item - total correlation berkisar 0.3 hingga 0.7 . Oleh sebab itu, butir-butir dari variabel $\mathrm{X}$ dan $\mathrm{Y}$ adalah valid $(>0.2)$.

Nisfiannoor (2013) menjelaskan bahwa reliabilitas mengacu pada konsistensi dari alat ukur tersebut apabila digunakan oleh indiviu yang berbeda atau waktu yang berbeda. Sedangkan Siregar (2013), reliabilitas dianggap cukup apabila alpha dihitung lebih besar dari 0,6. Berdasarkan hasil uji reliabilitas dari variabel Personal Selling (X) dan Minat Beli (Y): Nilai Cronbach's Alpha variabel X Personal Selling adalah 0,863 sedangkan nilai Cronbach's Alpha variabel Y Minat Beli adalah 0,789.

Hasil uji normalitas, variabel dependen yaitu Minat Beli (Y) memiliki nilai Asymp. Sig (2-tailed) sebesar 0,228. Hal ini menunjukkan data telah terdistribusi dengan normal $(0.228>0.05)$. Begitu juga dengan variabel independen yaitu Personal Selling (X) yang memiliki nilai Asymp. Sig (2-tailed) sebesar 0,101. Hal ini menunjukkan bahwa nilai 0,101 > 0,05 yang berarti data dari variabel independen Personal Selling (X) juga telah terdistribusi dengan normal atau bisa dikatakan, penyebaran suatu data merata ke responden-responden yang ada.

Koefisien korelasi menunjukkan kuat tidaknya hubungan linear dan arah hubungan. Apabila koefisien korelasi adalah positif, maka kedua variabel mempunyai hubungan searah, sehingga bila nilai variabel $X$ tinggi, maka nilai variabel Y juga tinggi. Sebaliknya apabila koefisien korelasi adalah negatif, maka kedua variabel mempunyai hubungan terbalik, nilai variabel $\mathrm{X}$ tinggi, maka nilai variabel Y rendah (Sarwono, 2009). Diperoleh kesimpulan bahwa nilai koefisien korelasi (R) untuk variabel Personal Selling (X) adalah sebesar 0,607 artinya hubungan antara $\mathrm{X}$ dan $\mathrm{Y}$ dikatakan tinggi atau kuat karena berada dalam interval 0,6-0,79. Hasil koefisien determinasi dengan menggunakan $R$ Square $\left(R^{2}\right)$ yaitu sebesar 0,369. Nilai tersebut menunjukkan kemampuan variabel Personal Selling (X) dalam menjelaskan variabel dependen minat beli (Y) adalah sebesar 36,9\%. Adapun sisanya sebesar $63,1 \%$ dijelaskan oleh faktor-faktor lain yang tidak dijelaskan dalam model regresi penelitian ini. Dalam jurnal penelitian yang lain dapat sebagai acuan untuk mendukung penelitian peneliti serta dapat menjelaskan sisa faktor faktor lain yang telah dihitung nilainya sebesar $63,1 \%$.

Variabel word of mouth memiliki pengaruh secara positif terhadap minat beli dengan diketahui nilai koefisien determinasi sebesar 32,9\%. Variabel iklan memiliki pengaruh secara signifikan terhadap minat beli dengan diketahui nilai koefisien determinasi sebesar 26\%, selain tentang word of mouth maupun iklan ada juga jurnal 
yang menjelaskan tentang promosi penjualan. Menurut Nursadiah (2018) variabel promosi penjualan memiliki pengaruh yang signifikan terhadap minat beli konsumen serta diketahui juga nilai koefisien determinasi sebesar 23,6\%.

Diperoleh hasil uji t untuk variabel personal selling adalah sebesar 9,395 dan signifikan ( Sig ) sebesar 0,000 $(<0.05)$. Dengan begitu menunjukkan Ha diterima, bahwa variabel $(\mathrm{X})$ personal selling memiliki pengaruh terhadap Minat beli (Y).

\section{Kesimpulan}

Terdapat pengaruh dari Personal Selling terhadap minat beli mengenai minat beli produk PRUlink Generasi Baru, hal ini sesuai dengan hasil uji t yang menunjukkan signifikan (Sig) 0,000, sehingga Ha disetujui dan memiliki pengaruh personal selling terhadap minat beli produk PRUlink Generasi Baru. Hasil Uji Validitas memiliki nilai di atas 0.200 , artinya variabel tersebut valid untuk diukur dan untuk uji reliabilitas diatas 0.600 , artinya memiliki nilai yang konsisten, layak untuk diteliti serta dapat diandalkan. Berdasarkan hasil uji koefisien korelasi terdapat hubungan antara personal selling terhadap minat beli produk PRUlink Generasi Baru sebesar 0,607, dan dapat dikategorikan tinggi atau kuat.

\section{Ucapan Terima Kasih}

Penulis pada kesempatan ini mengucapkan terima kasih kepada responden yang telah berkontribusi memberikan data guna pelaksanaan penelitian, Orang tua peneliti, Odilia Angeline yang setia membantu dan memberi dukungan emosional kepada peneliti.

\section{Daftar Pustaka}

Feist, J.,Feist, G.J., \& Roberts, T. (2013). Theories of personality ( $8^{\text {th }} E d$ ). New York: McGraw-Hill Education.

Kotler \& Keller. (2009). Manajemen Pemasaran. Jilid I. Edisi ke 13. Jakarta: Erlangga.

Kotler, Philip., \& Keller, Lane. (2012). Marketing Management. New Jersey: Prentice Hall.

Kotler, P. \& G. Armstrong. (2014). Principle of Marketing. 15th edition. New Jersey: Person Prentice Hall.

Kotler, P. \& G. Armstrong. (2016). Principle of Marketing. New Jersey: Person Prentice Hall.

Kriyantono, Rachmat. (2009). Teknik Praktis Riset Komunikasi. Malang: Prenada Media Group.

Machfoedz, Mahmud. (2010). Komunikasi Pemasaran Modern. Yogyakarta: Cakra Ilmu.

Morissan. (2012). Metode Penelitian Survey. Jakarta: Kencana Prenada Media Group.

Nisfiannoor, M. (2013). Pendekatan Statistika Modern. Jakarta: Universitas Trisakti.

Priansa, D. J. (2017). Komunikasi Pemasaran Terpadu Era Media Sosial. Bandung: Pustaka Setia Bandung.

Siregar, S. (2013). Metode Penelitian Kuantitatif. Jakarta: PT Fajar Interpratama Mandiri. 
Nico Aprianto, Diah Ayu Candraningrum: Pengaruh Personal Selling terhadap Minat Beli Produk

Sarwono, Jonathan. (2009). Statistik itu mudah : Panduan Lengkap untuk Belajar Komputerisasi Statistik Menggunakan SPSS 16. Yogyakarta: Andi.

Prudential. (2018). PRUlink Generasi Baru. September 8, 2019. https://www.prudential.co.id/id/our-products/product/prulink-generasi-baru/).

Rachim, U.A. ( 2018, Juli 24 ). 30 Best Insurance Companies - Referensi Investasi. Berita Satu database. https://www.beritasatu.com/ekonomi/502659/inipemenang-best-insurance-award-2018-versi-majalah-investor).

Sulaiman, F. ( 2019, April 1 ). Meski Penuh Gejolak, Prudential Tetap Pimpin Pasar Asuransi Indonesia, September 8, 2019. Warta Ekonomi Database. https://www.wartaekonomi.co.id/read221949/meski-penuh-gejolakprudential-tetap-pimpin-pasar-asuransi-indonesia.html ).

Worldometers. (2019). Informasi Populasi Indonesia di Dunia. September 8, 2019. https://www.worldometers.info/world-population/indonesia-population/)

Diyah, K., Kurniati, R.R., \& Zunaida, D.(2019). Pengaruh digital marketing terhadap minat beli asuransi PT. prudential life assurance cabang sukun. JIAGABI, $8(3), 165$.

Fatimah, N. (2018). Pengaruh resiliensi dan jiwa enterpreneurship terhadap prestasi kerja agen asuransi di PT. aj manulife indonesia cabang lotus surabaya. Media Mahardhika, 16(2), 193-201.

Ferdinand, A. T. (2016). Analisis pengaruh brand image dan personal selling terhadap keputusan pembelian pada produk human diagnostic (Studi pada PT. putra airlangga medika). Diponegoro Journal of Management, 5(3), 818-828.

Iskandar. (2016). Implementasi teori hirarki kebutuhan abraham maslow terhadap peningkatan kinerja pustakawan. Jurnal Ilmu Perpustakaan, Informasi, dan Kearsipan Khizanah Al- Hikmah, 4(1), 24-34.

Kusniadji, S. (2017). Kontribusi Penggunaan Personal Selling Dalam Kegiatan Komunikasi Pemasaran Pada Era Pemasaran Masa Kini. Jurnal Komunikasi, 9(2), 176-183. https://journal.untar.ac.id/index.php/komunikasi/article/view/1078

Muchina, C. M., \& Okello, B. (2016). Influence of personal selling on brand performance of retail shoe companies in Nairobi Central business district. International Journal of Academic Research and in Business and Social Sciences, 6(5).

Ningrum, I.T.J., \& Nilowardono, S. (2016). Pengaruh event dan brand image terhadap minat beli produk rokok Sampoerna A Mild pada PT HM Sampoerna area marketing Surabaya.Jurnal Manajemen Kinerja, 2(1), 61.

Riyanti, M. (2015). Pengaruh pengembangan produk terhadap minat beli konsumen pada vocuz evolute (Doctoral dissertation Universitas Widyatama).

Sarastuti, D. (2017). Strategi komunikasi pemasaran online produk busana muslim queenova. Jurnal Visi Komunikasi, 16(01), 71-90

Siregar, M. Y., \& Winita, W. (2017). Faktor- faktor yang mempengaruhi volume penjualan sparepart pada PT. calispo multi utama Medan. Jurnal Akuntansi dan Bisnis, 3(1). 